\title{
장기파랑관측자료와 수치실험에 의한 동해안 천해설계파고 검토 Comparison of the Shallow-Water Design Wave Height on the Korean East Coast Based on Wave Observation Data and Numerical Simulation
}

\author{
정원무* · 최혁진** · 조홍연* · 오상호* \\ Weon-Mu Jeong*, Hyukjin Choi**, Hong-Yeon Cho* and Sang-Ho Oh*
}

\begin{abstract}
요 지 : 본 연구에서는 동해안의 4 개 정점(속초, 묵호, 후포, 진하)에서 13 년간 관측된 파랑자료를 이용하여 극치 확률분석을 통해 재현빈도별로 천해설계파를 산정하였고, 이 값을 한국해양연구원(2005)에 제시된 동해안 심해설계 파를 이용하여 SWAN 수치모델링로 계산된 결과와 비교하였다. 그 결과 2005년 기존 심해설계파의 수치실험 결과 는 관측파랑에 의한 극치분석 결과보다 상대적으로 작은 것으로 나타났으며, 특히 30 년 빈도 이하에서 동해안에서 의 기존 심해설계파고가 과소산정되었을 가능성이 있음을 시사한다.
\end{abstract}

핵심용어 : 천해설계파, 연속파랑관측, 극치분석, 수치실험, 한국 동해안

\begin{abstract}
In this study, shallow-water design waves are estimated for various return periods based on statistical analysis of extreme waves observed 13 years at four stations on the Korean east coast (Sokcho, Mukho, Hupo, Jinha). These values are compared with the results from SWAN simulation by using the deep water design waves conventionally used in Korea (KORDI, 2005). It was found that the simulated values of the shallow-water design waves are comparatively smaller than the values from the extreme value analysis, expecially below 30 years frequency, which implies possible under-estimation of the deep-water design waves on the Korean east coast.
\end{abstract}

Keywords : shallow-water design wave, continuous wave observation, extreme value analysis, numerical analysis, Korean east coast

\section{1. 서 론}

항만 및 해안 구조물을 설계할 때는 50 년 빈도 설계파랑 등 의 빈도별 설계파랑 결정은 대단히 중요한 설계조건이며, 기 존의 빈도별 설계파랑 결정방법은 크게 2가지로 구분된다. 첫 번째 방법은 심해설계파의 정보를 이용하여 수치모델링을 통 해 천해설계파를 추산하는 것이다. 우리나라 전해역 심해설 계파를 추산하기 위하여 2005년 해양수산부는 해상파랑관측 조사사업’의 일환으로 53년간(1951년 2003년) 128개 태풍과 25년간(1979년 2003년)의 동계계절풍 자료를 분석하여 우리 나라 동해, 서해, 남해 심해설계파랑을 추산(전해역 심해설계 파 추정보고서II, 2005 한국해양연구원)하였으며, 이 자료는 최근까지 우리나라의 항만 및 어항구조물을 설계할 때 일반 적으로 사용되어 왔다. 당시 연구에서 Lee and Jun(2006)은 태풍시와 비태풍시를 구분하여 바람장과 파랑 발생 특성을 고 려하였다. 태풍의 경우 PVM (Primitive Vortex Model)을 사 용하여 바람장을 추정하고 WAM 모델을 사용하여 파랑장을
추산하였으며, 비태풍의 경우 1979년 2003년 ECMWF(유럽 중규모예보센터)의 바람자료를 입력하여 HYPA 모델을 통해 파랑자료를 산출하였다. 이와 같이 구분된 해상풍 자료를 입 력하여 수치모형실험으로 파랑을 역추산하고 추정격자점별로 확률분포함수에 적합시켜 빈도별 심해파랑을 추산하였다.

빈도별 설계파랑을 추산하는 두 번째 방법은 실제로 관측 된 장기 관측파랑 자료를 분석하여 빈도별 파랑결과를 해역 별로 추산하는 것이다. 이때 재현빈도 50 년 이상의 파랑을 추 산하기 위해서는 일반적으로 최소 20년 이상의 장기간 파랑 관측 자료가 필요하다. 우리나라 파랑관측은 기상청(KMA), 국립해양조사원(KHOA), 한국해양과학기술원(KIOST) 등에서 수행해 오고 있으며, Jeong et al.(2012, 2014, 2015, 2016) 은 우리나라 동해안의 연속 파랑관측자료 분석과 천해파 수 치실험을 통해 각 해역별 설계파를 비교.연구해 오고 있다. 기 상청의 동해안 파랑관측 자료는 동해부이의 경우 자료가 다 소 과소추정되는 것으로 분석되었고, 포항부이의 경우 관측 기간이 짧고 최근 결측율도 $15 \%$ 정도로 무시할 수 없을 정

\footnotetext{
*한국해양과학기술원 연안공학연구본부(Coastal and Environmental Engineering Division, Korea Institute of Ocean Science \& Technology) **(주)해안해양기술(Corresponding author: Hyukjin Choi, Coast and Ocean Technology Research Institute, A-2511 Hyundai Knowledge Industria Center, 70 Dusan-ro Geumcheon-gu, Seoul 08584, Korea, Tel: +82-2-2104-6600, Fax : +82-2-2104-6601, choi6000@gmail.com)
} 
도로 분석되며, 서해안 파랑관측 자료 또한 덕적도와 칠발도 부이자료가 1996년부터 시작된 장기간의 자료이지만 정확성 과 결측율에 대한 자세한 분석이 필요한 상태이다(Jeong et al., 2015).

본 연구의 파랑관측 자료는 한국해양과학기술원에서 수행한 파랑관측 자료중에서 동해안 천해역 4개 정점(속초, 묵호, 후 포, 진하)에서 약 13년간(2003년 2015년) 관측한 장기간 파랑 관측 자료를 사용하였으며, 2 가지 극치확률분포함수를 적용, 빈도분석을 수행하여 빈도별 천해설계파랑을 산정하였다. 또 한 현재 항만 설계시 일반적으로 사용되고 있는 심해설계파 추산자료(한국해양연구원, 2005)와 비교하기 위하여 제시된 빈 도별, 파향별 심해설계파 조건으로 SWAN(Simulating Waves Nearshore) 모델을 이용한 수치모형실험을 수행하여 4개 정 점의 빈도별 천해설계파랑을 구한 다음 파랑관측 자료로 2 가 지 극치분석을 통해서 얻은 빈도분석 결과와 상호 비교하였 다. 또한 관측기간 중에 출현한 상위 5 개의 최대파고를 역추 산된 심해설계파의 수치실험 결과와 비교하여 어느 정도의 빈 도에 해당하는지 분석하였다.

\section{2. 현장 관측자료 수집 및 분석}

\section{1 개 정점 파랑관측 자료분석}

한국해양과학기술원(KIOST)은 동해안 4개소(속초, 묵호, 후 포, 진하)에서 10 여년 전부터 수심 $15.0 \sim 18.5 \mathrm{~m}$ 에서 수압식 파고계(WTG; Wave and Tide Gage)를 설치하여 현재까지 파랑관측을 수행해오고 있다. 4 개 관측정점의 위치도와 경위 도, 수심, 관측기간 등에 대한 정보를 Fig. 1과 Table 1에 제 시하였다. 이들 관측점은 외해측을 향해 개방적인 해역에 위 치하고 있으며 암초나 주변지형 등에 의해 영향을 받지 않는 파랑관측에 적합한 곳에 위치하고 있다.

Jeong et al. (2007)에 제시된 것처럼 수압식 파고계의 자 료수집 시간 간격은 0.5 초이며, 30 분마다 2,048 개의 자료를 사용하여 파 스펙트럼을 계산하였다. 스펙트럼 분석법을 통 하여 파 스펙트럼으로부터 유의파고 $\left(H_{s}\right)$ 로 불리는 유의파고 추정치 $\left(H_{m 0}\right)$ 및 첨두주기 $\left(T_{p}\right)$ 를 계산하였다. 유의파고 추정치 는 아래 식으로 정의되며,

$$
H_{m 0}=4 \sqrt{m_{0}}
$$

여기서 $m_{n}$ 은 아래와 같이 계산되는 스펙트럼 밀도의 $n$ 차 모
멘트이다. 한편 첨두주기는 파 스펙트럼이 최대가 되는 주파 수에 해당하는 주기(=주파수의 역수)이다.

$$
m_{n}=\int_{f_{1}}^{f_{2}} f^{n} \cdot S(f) d f
$$

한편, 식 (2)에서 $f$ 는 파의 주파수, $S(f)$ 는 파의 스펙트럼 밀도를 각각 나타낸다. 여기서 하한 절단주파수(low cutoff frequency)는 $f_{1}=5 / 128 \mathrm{~Hz}$ 로, 상한 절단주파수(high cutoff frequency)는 $f_{2}=64 / 128 \mathrm{~Hz}$ 로 설정하였다.

\section{2 연최대 유의파와 연2위 유의파 분석}

2003년부터 2015년까지 4개 관측정점에서 관측된 유의파고 를 크기 순서로 나열할 때 연중 가장 큰 파고(연최대 유의파, $\mathrm{Hs}_{1}$ 로 표기)와 두 번째 큰 파고(연2위 유의파, $\mathrm{Hs}_{2}$ 로 표기)를 대상으로 자료를 정리(Table 2 참조)하여 유의파 분석을 수행

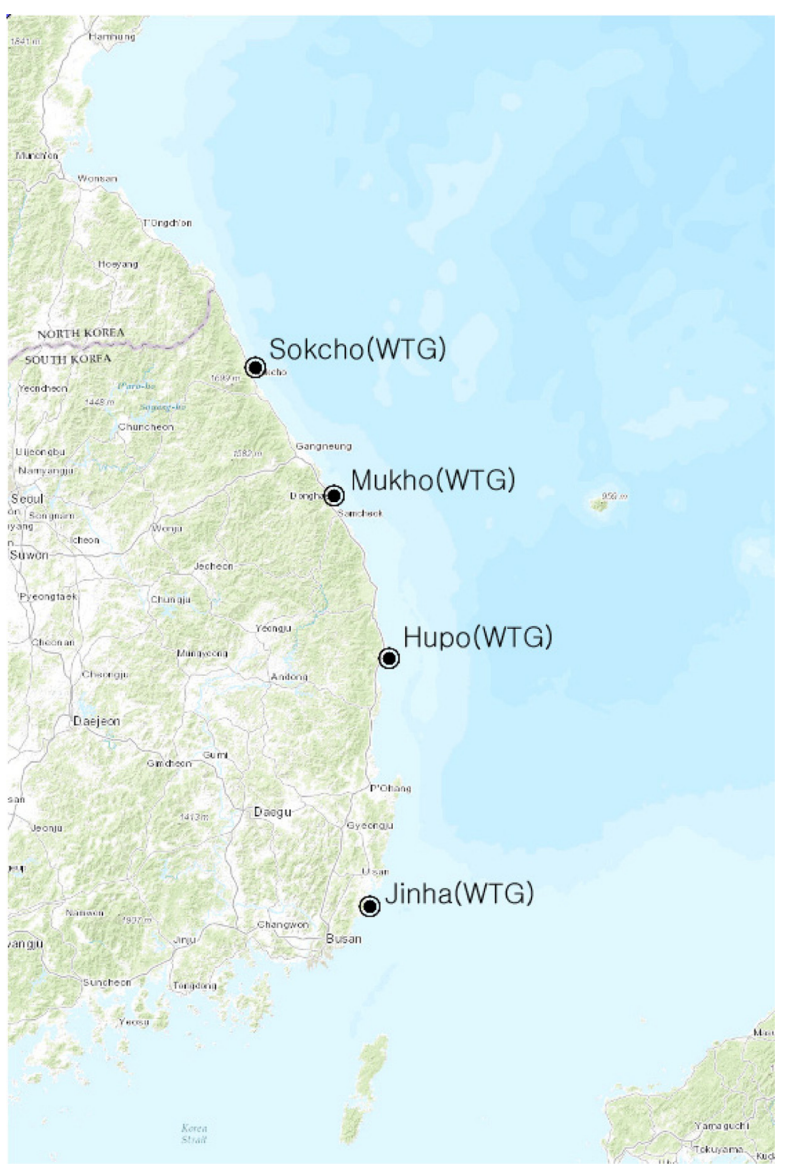

Fig. 1. Location map of the wave observation stations.

\begin{tabular}{|c|c|c|c|c|}
\hline St. & Coordinate & Depth (m) & Instrument & Monitoring period \\
\hline $\mathrm{SC}$ & $38^{\circ} 12^{\prime} 27.9^{\prime \prime} \mathrm{N}, 128^{\circ} 36^{\prime} 59.6^{\prime \prime} \mathrm{E}$ & 18.5 & WTG & 2003. 03. 24 2015. 12. 31 \\
\hline $\mathrm{MH}$ & $37^{\circ} 32^{\prime} 52.5^{\prime \prime} \mathrm{N}, 129^{\circ} 07^{\prime} 30.4^{\prime \prime} \mathrm{E}$ & 15.0 & WTG & 2004. 03. 07 2015. 12. 31 \\
\hline $\mathrm{HP}$ & $36^{\circ} 41^{\prime} 59.1^{\prime \prime} \mathrm{N}, 129^{\circ} 29^{\prime} 03.4^{\prime \prime} \mathrm{E}$ & 17.5 & WTG & 2006. 05. 04 2015. 12. 31 \\
\hline $\mathrm{JH}$ & $35^{\circ} 23^{\prime} 11.1^{\prime \prime} \mathrm{N}, 129^{\circ} 21^{\prime} 38.1^{\prime \prime} \mathrm{E}$ & 18.0 & WTG & 2003. 08. 07 2015. 12. 31 \\
\hline
\end{tabular}

Table 1. Information of the wave observation stations (SC:Sokcho, MH:Mukho, HP:Hupo, JH:Jinha). 
Table 2. Values of $\mathrm{Hs}_{1}$ and $\mathrm{Hs}_{2}$ observed at the four wave stations.

\begin{tabular}{|c|c|c|c|c|c|c|c|c|c|c|c|c|c|}
\hline \multirow{2}{*}{ 연도 } & \multirow{2}{*}{ index } & \multicolumn{3}{|c|}{ Sokcho } & \multicolumn{3}{|c|}{ Mukho } & \multicolumn{3}{|c|}{ Hupo } & \multicolumn{3}{|c|}{ Jinha } \\
\hline & & Time & $\mathrm{H}(\mathrm{m})$ & $\mathrm{T}(\mathrm{s})$ & Time & $\mathrm{H}(\mathrm{m})$ & $\mathrm{T}(\mathrm{s})$ & Time & $\mathrm{H}(\mathrm{m})$ & $\mathrm{T}(\mathrm{s})$ & Time & $\mathrm{H}(\mathrm{m})$ & $\mathrm{T}(\mathrm{s})$ \\
\hline \multirow{2}{*}{2003} & $\mathrm{Hs}_{1}$ & $12.1514: 00$ & 4.10 & 9.85 & - & - & - & - & - & - & 09.12 23:00 & (1) 7.52 & 15.07 \\
\hline & $\mathrm{Hs}_{2}$ & $11.2711: 00$ & 3.85 & 9.14 & - & - & - & - & - & - & $11.2810: 30$ & 2.98 & 9.85 \\
\hline \multirow{2}{*}{2004} & $\mathrm{Hs}_{1}$ & 04.27 17:00 & (3) 5.64 & 11.64 & 04.27 17:00 & 4.96 & 10.67 & - & - & - & 08.19 08:30 & (4) 5.44 & 9.85 \\
\hline & $\mathrm{Hs}_{2}$ & $02.23 \quad 17: 30$ & 4.44 & 10.67 & $12.0521: 00$ & 4.95 & 12.80 & - & - & - & $10.2110: 00$ & 3.19 & 11.64 \\
\hline \multirow{2}{*}{2005} & $\mathrm{Hs}_{1}$ & 01.16 05:00 & (4) 5.49 & 10.67 & 01.16 06:30 & (2) 6.52 & 11.64 & - & - & - & $10.2307: 00$ & 4.88 & 12.80 \\
\hline & $\mathrm{Hs}_{2}$ & $10.2122: 30$ & (5) 5.37 & 11.64 & $10.2122: 30$ & (3) 6.45 & 12.80 & - & - & - & $12.0602: 30$ & 4.81 & 12.80 \\
\hline \multirow{2}{*}{2006} & $\mathrm{Hs}_{1}$ & $10.2311: 00$ & (1) 8.95 & 12.80 & $10.2315: 30$ & (1) 8.37 & 12.80 & 09.18 07:00 & (1) 5.94 & 10.67 & $10.2402: 00$ & (2) 5.96 & 12.80 \\
\hline & $\mathrm{Hs}_{2}$ & 09.18 19:00 & 5.16 & 12.80 & 09.18 11:00 & 4.77 & 11.64 & $10.2321: 30$ & (4) 5.37 & 14.22 & 09.17 22:00 & (3) 5.82 & 10.67 \\
\hline \multirow{2}{*}{2007} & $\mathrm{Hs}_{1}$ & $11.1106: 00$ & 3.53 & 9.14 & 09.08 14:30 & 4.52 & 11.64 & $11.1113: 30$ & 3.37 & 9.85 & 01.08 20:00 & 3.21 & 12.80 \\
\hline & $\mathrm{Hs}_{2}$ & 07.10 23:00 & 3.44 & 8.53 & $11.1110: 00$ & 4.19 & 9.85 & $11.2823: 30$ & 3.31 & 8.53 & 07.14 22:00 & 2.87 & 9.14 \\
\hline \multirow{2}{*}{2008} & $\mathrm{Hs}_{1}$ & $12.2116: 00$ & 3.75 & 9.85 & $12.21 \quad 17: 00$ & 4.98 & 9.85 & $01.2101: 30$ & 4.19 & 9.85 & 01.21 05:00 & 4.69 & 10.67 \\
\hline & $\mathrm{Hs}_{2}$ & 03.19 15:00 & 3.58 & 9.14 & 02.24 13:00 & 4.75 & 11.64 & $02.2423: 00$ & 4.16 & 14.22 & $02.2420: 00$ & 4.32 & 12.80 \\
\hline \multirow{2}{*}{2009} & $\mathrm{Hs}_{1}$ & $04.2520: 00$ & 3.9 & 9.85 & 6 06:30 & 5.03 & 10.67 & $: 00$ & (5) 5.06 & 10.67 & 1 09:00 & (5) 5.42 & 12.80 \\
\hline & $\mathrm{Hs}_{2}$ & 11.11 13:30 & 3.93 & 10.67 & $11.0213: 30$ & 4.96 & 11.64 & $11.1108: 30$ & 4.80 & 10.67 & $10.0811: 00$ & 4.85 & 11.64 \\
\hline \multirow{2}{*}{2010} & $\mathrm{Hs}_{1}$ & $05.2322: 30$ & 3.50 & 8.53 & $10.2602: 00$ & 3.86 & 9.85 & 02.11 13:00 & 3.27 & 7.53 & $02.11 \quad 14: 00$ & 4.32 & 9.85 \\
\hline & $\mathrm{Hs}_{2}$ & $09.21 \quad 19: 00$ & 3.48 & 9.14 & $05.2612: 30$ & 3.77 & 10.67 & $05.2321: 00$ & 3.32 & 10.67 & 03.01 19:00 & 3.83 & 9.85 \\
\hline \multirow{2}{*}{2011} & $\mathrm{Hs}_{1}$ & $01.01 \quad 12: 30$ & 4.07 & 12.80 & 01.01 08:00 & (4) 6.04 & 14.22 & 01.01 11:30 & (3) 5.46 & 12.80 & 01.01 14:30 & 5.21 & 12.80 \\
\hline & $\mathrm{Hs}_{2}$ & $12.0821: 00$ & 4.02 & 10.67 & $12.0819: 00$ & 4.75 & 11.64 & $02.1204: 30$ & 4.11 & 8.00 & $09.2121: 00$ & 4.28 & 10.67 \\
\hline \multirow{2}{*}{2012} & $\mathrm{Hs}_{1}$ & $04.03 \quad 12: 00$ & 5.30 & 085 & 09.17 17:00 & 5.53 & 11.64 & 09.17 17:00 & 4.18 & 8.53 & 01.19 18:00 & 3.50 & 9.14 \\
\hline & $\mathrm{Hs}_{2}$ & 09.17 19:00 & 5.25 & 11.64 & 04.03 16:00 & 4.85 & 11.64 & $08.2814: 00$ & 4.01 & 8.00 & 09.17 13:00 & 3.47 & 9.14 \\
\hline \multirow{2}{*}{2013} & $\mathrm{Hs}_{1}$ & $12.2020: 30$ & (2) 6.07 & 12.80 & $12.2019: 30$ & (5) 5.58 & 14.22 & $12.2019: 30$ & 4.72 & 12.80 & $10.1614: 30$ & 4.12 & 10.67 \\
\hline & $\mathrm{Hs}_{2}$ & $04.0622: 00$ & 4.30 & 9.85 & 10.15 13:30 & 5.06 & 10.67 & $10.1613: 30$ & 4.46 & 10.67 & $02.0821: 30$ & 3.46 & 12.80 \\
\hline \multirow{2}{*}{2014} & $\mathrm{Hs}_{1}$ & $10.1311: 30$ & 4.50 & 10.67 & $10.1311: 30$ & 5.04 & 9.85 & $10.1314: 30$ & 4.76 & 9.85 & 10.13 13:00 & 5.38 & 10.67 \\
\hline & $\mathrm{Hs}_{2}$ & 09.30 07:00 & 3.85 & 9.14 & $09.3010: 00$ & 4.62 & 9.85 & 03.13 10:00 & 3.73 & 8.53 & $12.1906: 30$ & 3.76 & 14.22 \\
\hline \multirow{2}{*}{2015} & $\mathrm{Hs}_{1}$ & $08.2601: 00$ & 4.78 & 10.67 & $11.2704: 00$ & 5.48 & 12.80 & $08.2519: 00$ & (2) 5.60 & 10.67 & $08.25 \quad 13: 30$ & 5.32 & 11.64 \\
\hline & $\mathrm{Hs}_{2}$ & 11.26 23:00 & 4.55 & 12.80 & $08.2606: 30$ & 5.35 & 10.67 & $11.2709: 30$ & 4.81 & 14.22 & 11.18 15:30 & 3.56 & 9.85 \\
\hline
\end{tabular}

하였다. 이 때 각 정점별 큰 파고 순서대로 (1) (5)로 표기하였 다. 이를 살펴보면, 2003년 태풍“매미”의 영향을 받은 진하의 연최대 유의파 $(7.52 \mathrm{~m}, 15.07 \mathrm{~s})$ 를 제외하면 4 개 정점의 연최 대 유의파는 모두 2006년에 발생하였으며 속초와 묵호는 $8.0 \mathrm{~m}$ 이상 (속초 $8.95 \mathrm{~m}, 12.80 \mathrm{~s}$, 묵호 $8.37 \mathrm{~m}, 12.80 \mathrm{~s}$ )의 고 파랑이 내습하였다. 이는 2006년 10월 23일 24일 중국 화베 이 지방에서 생성된 온대성 저기압이 동해를 느린 속도로 통 과하며 전달된 너울성 파랑에 의한 영향과, 2006년 9월 17일 $\sim 18$ 일 최저 중심기압 $919 \mathrm{hPa}$ 의 태풍“산산”에 의한 영향으로 판단된다. 연 2 위 유의파는 속초에서 $6.07 \mathrm{~m}$, 묵호에서 $6.52 \mathrm{~m}$, 후포에서 $5.60 \mathrm{~m}$, 진하에서 $5.96 \mathrm{~m}$ 로 나타나, 관측기간 중 연 최대 유의파와 제 2 위 유의파의 파고 차이가 속초는 $2.9 \mathrm{~m}$, 묵 호는 $1.9 \mathrm{~m}$, 진하는 $1.6 \mathrm{~m}$ 로 크게 나타났다. 후포의 경우는 연 최대 유의파와 제 2 위 유의파의 파고차이가 $0.3 \mathrm{~m}$ 로 상대적으 로 작은 것으로 나타났는데 이는 2003년 태풍“매미”와 2005 년 10 월 21 일 24 일 온대성 저기압에 의한 동해안의 너울성 파 랑 발생시 후포의 관측자료 부재에 따른 것으로 판단된다.

\section{3. 관측파랑을 이용한 빈도별 천해설계파 추산}

4개 관측점에서 수행한 관측파랑 중 연최대 유의파 $\left(\mathrm{Hs}_{1}\right)$ 또는 연2위 유의파 $\left(\mathrm{Hs}_{1}, \mathrm{Hs}_{2}\right)$ 까지를 대상으로 2가지 확률분 포함수에 적합시키고 적합도 검증 $(\mathrm{K}-\mathrm{S}$ test $)$ 을 수행하여 최 적의 빈도별 천해설계파를 추산하였다. 빈도별 천해설계파 추산에는 주로 극치분포 해석이 많이 사용되며, Goda(2010) 는 일본 해안에서 관측파랑 자료를 분석하여 4 개의 Weibull 극치분포형을 제안하였다. 본 연구에서는 극치분포형 중에 서 매개변수가 3 개인 제3형 Weibull 분포함수와 비모수적 방법인 Kernel 분포함수를 선정하고 $\mathrm{Hs}_{1}$ 와 $\mathrm{Hs}_{2}$ 을 각각 입 력하고 극치분석을 수행하여 재현빈도별 천해설계파고를 추 산하였다.

먼저, Weibull 분포함수의 누적분포함수와 확률밀도함수는 다음과 같다.

$$
F(x)=1-\exp \left[-\left(-\frac{x-B}{A}\right)^{k}\right]: k>0, B \leq x<\infty
$$




$$
f(x)=\frac{x}{A}\left(\frac{x-B}{A}\right)^{k-1} \exp \left[-\left(\frac{x-B}{A}\right)^{k}\right]
$$

여기서, $A$ 는 규모매개변수, $B$ 는 위치매개변수, $k$ 는 형상매개 변수이며, $k=1$ 이면 지수분포와 같다.

Kernel 분포함수의 누적분포함수와 확률밀도함수는 다음과 같다.

$$
\begin{aligned}
& F(x)=\int_{-\infty}^{x} \frac{1}{n h} \sum_{i=1}^{n} K\left(\frac{x-x_{i}}{h}\right) d x \\
& f(x)=\frac{1}{n h} \sum_{i=1}^{n} K\left(\frac{x-x_{i}}{h}\right)
\end{aligned}
$$

여기서, $K$ 는 Gaussian Kernel 함수로 $K(x)=(1 / \sqrt{2 \pi})$ $\cdot \exp \left(-x^{2} / 2\right)$ 이며, $h$ 는 Kernel 함수 대역폭(bandwidth) 파 라미터이다.

Weibull 분포함수의 매개변수 추정방법은 모멘트법, 확 률가중모멘트법, L-모멘트법, 최우도법, 최소자승법 등으로
구분되며, 본 연구에서는 최소자승법(Least Square Method)을 사용하였다. 각 확률분포형의 추산결과는 빈도 별로 파고를 추정하고 서로 비교하여 Table 3과 Fig. 2에 나타내었다.

극치분석에서 활용한 파랑의 관측기간은 약 10 년 13 년 간이며, 이는 확률분포함수를 통해 약 20 년 30년 이상의 빈도 추정시 신뢰도에서 문제가 있을 것으로 판단된다. 그 러나 5년 20년빈도의 추산결과는 실제적인 관측파랑이 반 영된 측면에서 신뢰도가 높을 수 있으며, 구조물 공사시 또 는 단기간의 구조물 안전성 검토시에 유용하게 사용될 수 있을 것으로 판단된다. 또한 Fig. 2에서 보는 바와 같이 30 년빈도 이상의 결과에서도 분포형에 따라 전체적인 경 향성을 잘 재현하고 있는 것으로 판단된다.

빈도별 파고 추산결과를 살펴보면, 제2위 유의파까지 고 려한 경우 $\left(\mathrm{Hs}_{1}\right.$ 와 $\left.\mathrm{Hs}_{2}\right)$ 의 추산결과가 연최대 유의파만 고 려한 경우 $\left(\mathrm{Hs}_{1}\right)$ 보다 묵호, 후포, 진하에서 더 크게 나타났

\begin{tabular}{|c|c|c|c|c|c|c|c|c|}
\hline \multicolumn{9}{|c|}{ (a) Results using only $\mathrm{Hs}_{1}$} \\
\hline \multirow{2}{*}{ Return Period(yr) } & \multicolumn{2}{|c|}{ Sokcho(m) } & \multicolumn{2}{|c|}{ Mukho(m) } & \multicolumn{2}{|c|}{ Hupo(m) } & \multicolumn{2}{|c|}{ Jinha(m) } \\
\hline & Weibull & Kernel & Weibull & Kernel & Weibull & Kernel & Weibull & Kernel \\
\hline 5 & 5.60 & 5.74 & 6.21 & 6.11 & 5.45 & 5.55 & 5.95 & 5.80 \\
\hline 10 & 6.75 & 6.49 & 7.06 & 6.77 & 5.85 & 5.94 & 6.50 & 6.37 \\
\hline 20 & 7.98 & 8.64 & 7.93 & 8.30 & 6.21 & 6.24 & 6.97 & 7.34 \\
\hline 30 & 8.74 & 9.00 & 8.45 & 8.44 & 6.40 & 6.39 & 7.21 & 7.60 \\
\hline 40 & 9.29 & 9.19 & 8.81 & 8.52 & 6.53 & 6.49 & 7.37 & 7.74 \\
\hline 50 & 9.73 & 9.31 & 9.10 & 8.58 & 6.62 & 6.56 & 7.49 & 7.83 \\
\hline 60 & 10.09 & 9.40 & 9.33 & 8.62 & 6.69 & 6.62 & 7.58 & 7.90 \\
\hline 70 & 10.40 & 9.46 & 9.53 & 8.65 & 6.75 & 6.66 & 7.66 & 7.96 \\
\hline 80 & 10.67 & 9.52 & 9.70 & 8.68 & 6.80 & 6.70 & 7.73 & 8.00 \\
\hline 90 & 10.91 & 9.57 & 9.85 & 8.70 & 6.85 & 6.73 & 7.79 & 8.04 \\
\hline 100 & 11.12 & 9.61 & 9.99 & 8.72 & 6.89 & 6.76 & 7.84 & 8.07 \\
\hline \multicolumn{9}{|c|}{ (b) Results using both $\mathrm{Hs}_{1}$ and $\mathrm{Hs}_{2}$} \\
\hline \multirow{2}{*}{ Return Period(yr) } & \multicolumn{2}{|c|}{ Sokcho(m) } & \multicolumn{2}{|c|}{ Mukho(m) } & \multicolumn{2}{|c|}{ Hupo(m) } & \multicolumn{2}{|c|}{$\operatorname{Jinha}(\mathrm{m})$} \\
\hline & Weibull & Kernel & Weibull & Kernel & Weibull & Kernel & Weibull & Kernel \\
\hline 5 & 6.03 & 5.79 & 6.45 & 6.38 & 5.50 & 5.63 & 6.01 & 6.11 \\
\hline 10 & 6.75 & 6.49 & 7.06 & 6.77 & 5.85 & 5.94 & 6.55 & 6.69 \\
\hline 20 & 7.86 & 8.73 & 8.81 & 8.52 & 6.53 & 6.49 & 7.04 & 7.35 \\
\hline 30 & 8.41 & 8.99 & 9.33 & 8.62 & 6.69 & 6.62 & 7.31 & 7.66 \\
\hline 40 & 8.81 & 9.12 & 9.70 & 8.68 & 6.80 & 6.70 & 7.49 & 7.85 \\
\hline 50 & 9.12 & 9.20 & 9.99 & 8.72 & 6.89 & 6.76 & 7.62 & 7.98 \\
\hline 60 & 9.37 & 9.26 & 10.23 & 8.75 & 6.95 & 6.81 & 7.73 & 8.07 \\
\hline 70 & 9.58 & 9.31 & 10.43 & 8.77 & 7.01 & 6.85 & 7.82 & 8.15 \\
\hline 80 & 9.77 & 9.35 & 10.60 & 8.79 & 7.06 & 6.89 & 7.90 & 8.21 \\
\hline 90 & 9.94 & 9.38 & 10.75 & 8.81 & 7.10 & 6.92 & 7.97 & 8.27 \\
\hline 100 & 10.08 & 9.41 & 10.89 & 8.83 & 7.13 & 6.94 & 8.03 & 8.31 \\
\hline
\end{tabular}
으며, 속초는 50 년빈도 이상의 결과에서 그 반대의 경향

Table 3. Extreme values of the significant wave height at the four wave stations. 

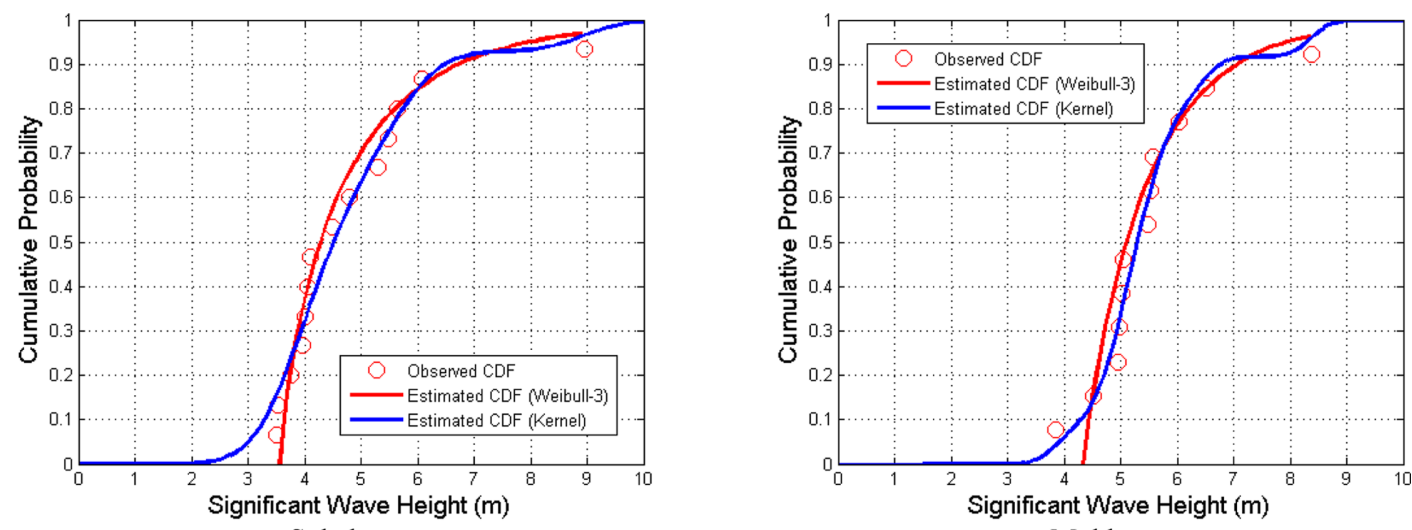

Sokcho

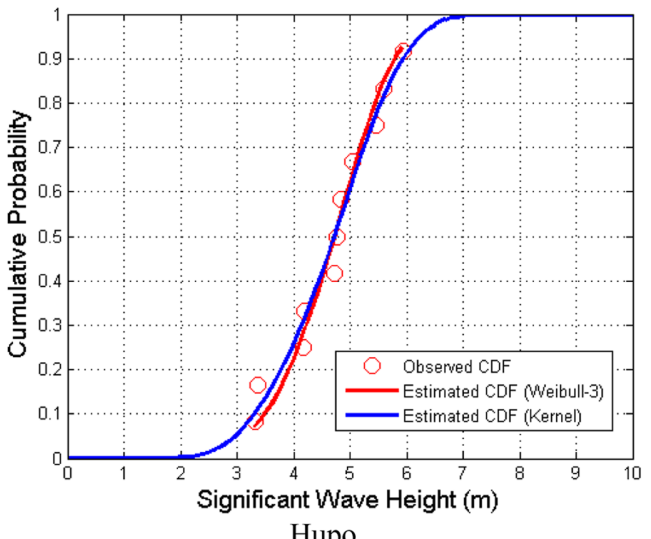

Mukho

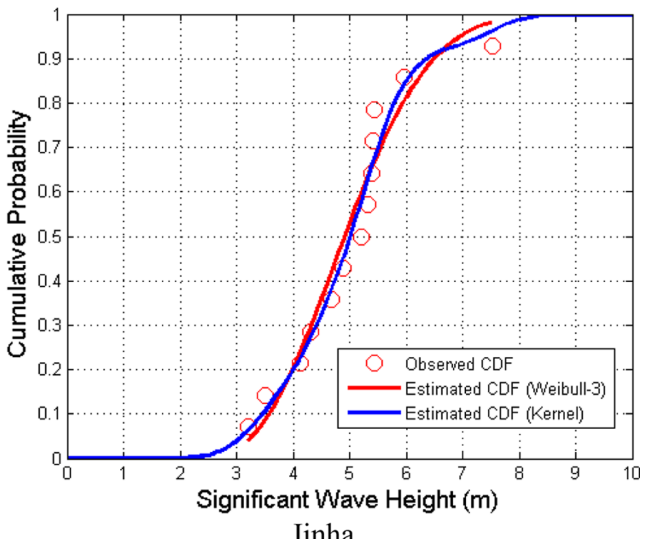

(a) Results using only $\mathrm{Hs}_{1}$
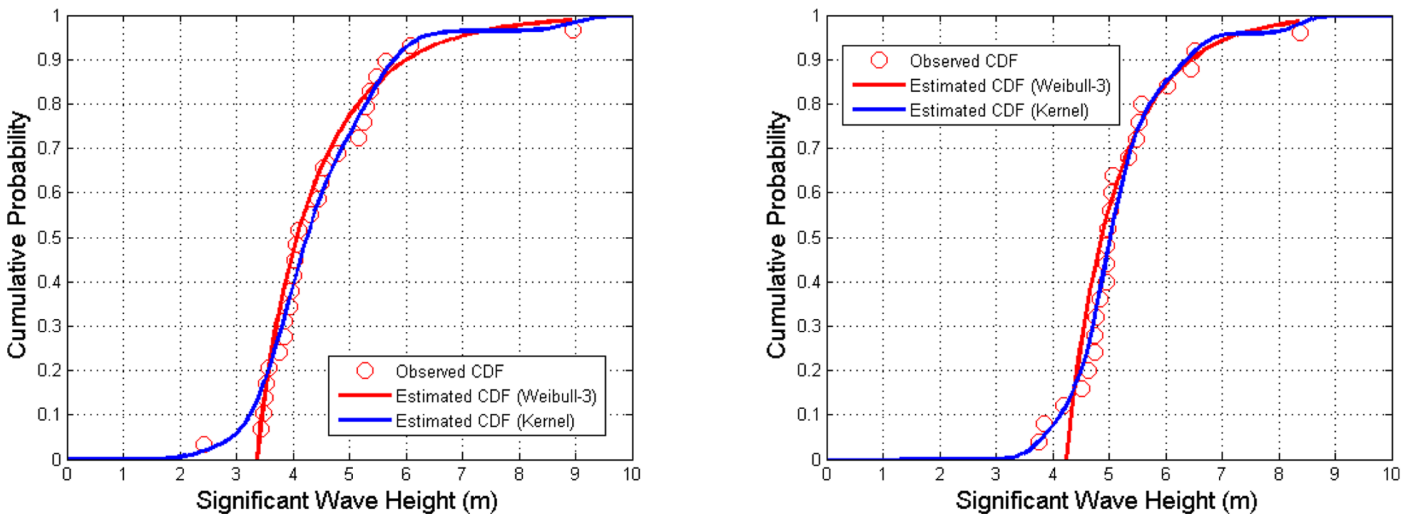

Sokcho

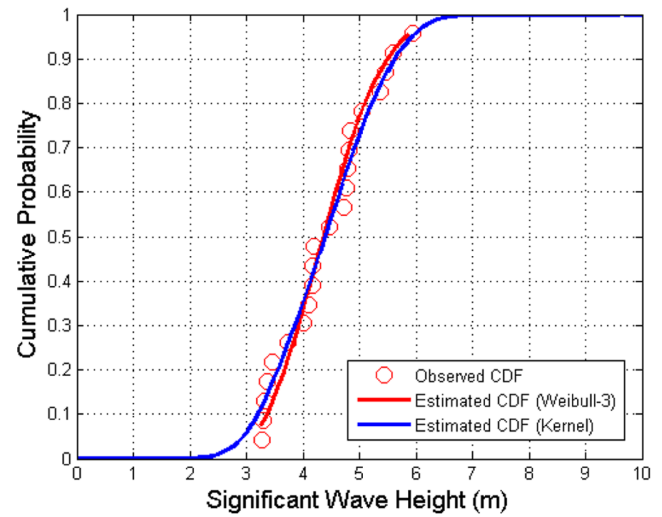

Hupo

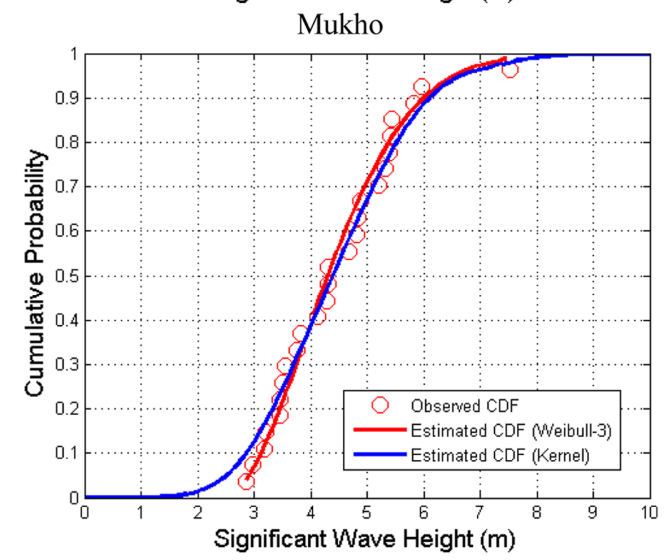

Jinha

(b) Results using both $\mathrm{Hs}_{1}$ and $\mathrm{Hs}_{2}$

Fig. 2. Cumulative probability distributions of the significant wave height at the four wave stations. 
을 나타내었다. 또한 Weibull 분포형의 결과가 Kernel 분 포형의 결과보다 대부분 더 큰 파고로 추산되었지만, 관 측파랑을 재현하는 적합도 측면에서는 Weibull 분포형보 다 Kernel 분포형의 추산결과가 더욱 적합한 결과로 나 타났다.

\section{4. 역추산된 심해설계파를 이용한 천해설계파 수치실험}

한국해양연구원(2005)에서 역추산한 심해설계파를 입력자 료(Table 4의 $\mathrm{H}_{\mathrm{o}}$ 와 $\mathrm{T}_{0}$ 로 표시)로 활용하여 SWAN 모형을 통

Table 4. Results of numerical simulation for return period of 10, 20, 30, 50, 100 years.

\begin{tabular}{|c|c|c|c|c|c|c|c|c|c|c|c|c|c|}
\hline \multirow{2}{*}{\multicolumn{2}{|c|}{$\begin{array}{l}\text { Return Period } \\
\text { (yr) }\end{array}$}} & \multicolumn{6}{|c|}{ Sokcho } & \multicolumn{6}{|c|}{ Mukho } \\
\hline & & NNE & $\mathrm{NE}$ & ENE & $E$ & ESE & $\mathrm{SE}$ & NNE & $\mathrm{NE}$ & ENE & $\mathrm{E}$ & ESE & $\mathrm{SE}$ \\
\hline \multirow{5}{*}{10} & & & & & & & & & & & & & \\
\hline & $\mathrm{H}_{\mathrm{o}}(\mathrm{m})$ & 4.15 & 5.28 & 4.79 & 4.22 & 4.02 & 3.31 & 5.97 & 5.86 & 5.31 & 4.36 & 3.90 & 4.42 \\
\hline & $\mathrm{H}_{\mathrm{p}}(\mathrm{m})$ & 3.70 & 4.72 & 4.25 & 3.79 & 3.53 & 2.66 & 4.54 & 4.75 & 4.39 & 3.51 & 3.05 & 2.94 \\
\hline & $\mathrm{T}_{\mathrm{o}}(\mathrm{s})$ & 9.04 & 10.33 & 9.68 & 8.99 & 8.42 & 7.71 & 11.23 & 11.20 & 10.41 & 9.35 & 8.61 & 9.01 \\
\hline & $\mathrm{T}_{\mathrm{p}}(\mathrm{s})$ & 9.39 & 10.34 & 9.39 & 8.52 & 8.52 & 7.74 & 11.70 & 11.70 & 10.64 & 9.68 & 8.81 & 8.81 \\
\hline \multirow{4}{*}{20} & $\mathrm{H}_{\mathrm{o}}(\mathrm{m})$ & 4.59 & 5.60 & 4.97 & 4.55 & 5.24 & 4.21 & 6.51 & 6.19 & 5.86 & 5.39 & 4.76 & 5.67 \\
\hline & $\mathrm{H}_{\mathrm{p}}(\mathrm{m})$ & 4.08 & 4.99 & 4.41 & 4.09 & 4.55 & 3.30 & 5.01 & 5.04 & 4.89 & 4.57 & 3.76 & 3.91 \\
\hline & $\mathrm{T}_{\mathrm{o}}(\mathrm{s})$ & 9.51 & 10.64 & 9.87 & 9.34 & 9.61 & 8.70 & 11.72 & 11.51 & 10.93 & 10.77 & 9.51 & 10.20 \\
\hline & $\mathrm{T}_{\mathrm{p}}(\mathrm{s})$ & 9.39 & 10.34 & 9.39 & 9.39 & 9.39 & 8.52 & 11.70 & 11.70 & 10.64 & 10.64 & 9.68 & 10.64 \\
\hline \multirow{4}{*}{30} & $\mathrm{H}_{\mathrm{o}}(\mathrm{m})$ & 4.82 & 5.77 & 5.07 & 5.00 & 6.00 & 4.73 & 6.80 & 6.36 & 6.30 & 6.23 & 5.25 & 6.42 \\
\hline & $\mathrm{H}_{\mathrm{p}}(\mathrm{m})$ & 4.28 & 5.14 & 4.49 & 4.42 & 5.21 & 3.65 & 5.25 & 5.18 & 5.46 & 5.44 & 4.16 & 4.53 \\
\hline & $\mathrm{T}_{\mathrm{o}}(\mathrm{s})$ & 9.75 & 10.80 & 9.96 & 9.41 & 10.29 & 9.22 & 11.99 & 11.67 & 11.80 & 11.57 & 9.99 & 10.86 \\
\hline & $\mathrm{T}_{\mathrm{p}}(\mathrm{s})$ & 9.39 & 10.34 & 10.34 & 9.39 & 10.34 & 9.39 & 11.70 & 11.70 & 11.70 & 11.70 & 9.68 & 10.64 \\
\hline \multirow{4}{*}{50} & $\mathrm{H}_{\mathrm{o}}(\mathrm{m})$ & 5.10 & 5.97 & 5.18 & 5.58 & 6.99 & 5.38 & 7.16 & 6.57 & 7.44 & 7.33 & 5.87 & 7.40 \\
\hline & $\mathrm{H}_{\mathrm{p}}(\mathrm{m})$ & 4.53 & 5.33 & 4.59 & 4.91 & 6.05 & 4.06 & 5.55 & 5.35 & 6.59 & 6.61 & 4.62 & 4.88 \\
\hline & $\mathrm{T}_{\mathrm{o}}(\mathrm{s})$ & 10.03 & 10.98 & 10.07 & 9.94 & 11.11 & 9.83 & 12.30 & 11.86 & 12.83 & 12.55 & 10.56 & 11.66 \\
\hline & $\mathrm{T}_{\mathrm{p}}(\mathrm{s})$ & 10.34 & 11.39 & 10.34 & 10.34 & 11.39 & 9.39 & 12.86 & 11.70 & 12.86 & 12.86 & 10.64 & 11.70 \\
\hline \multirow{4}{*}{100} & $\mathrm{H}_{\mathrm{o}}(\mathrm{m})$ & 5.47 & 6.22 & 5.32 & 6.36 & 8.42 & 6.26 & 7.63 & 6.83 & 9.03 & 8.91 & 6.71 & 8.76 \\
\hline & $\mathrm{H}_{\mathrm{p}}(\mathrm{m})$ & 4.85 & 5.56 & 4.72 & 5.57 & 7.28 & 4.61 & 5.95 & 5.56 & 7.91 & 8.03 & 5.44 & 6.51 \\
\hline & $\mathrm{T}_{\mathrm{o}}(\mathrm{s})$ & 10.38 & 11.21 & 10.21 & 10.61 & 12.19 & 10.60 & 12.69 & 12.19 & 14.13 & 13.83 & 11.29 & 12.69 \\
\hline & $\mathrm{T}_{\mathrm{p}}(\mathrm{s})$ & 10.34 & 11.39 & 10.34 & 10.34 & 12.54 & 10.34 & 12.86 & 11.70 & 14.13 & 14.13 & 11.70 & 12.86 \\
\hline \multirow{2}{*}{\multicolumn{2}{|c|}{$\begin{array}{l}\text { Return Period } \\
(\mathrm{yr})\end{array}$}} & \multicolumn{6}{|c|}{ Hupo } & \multicolumn{6}{|c|}{ Jinha } \\
\hline & & $\begin{array}{c}\mathrm{NE} \\
077110\end{array}$ & $\begin{array}{c}\text { ENE } \\
077111\end{array}$ & $\begin{array}{c}\mathrm{E} \\
077111\end{array}$ & $\begin{array}{c}\text { ESE } \\
077112\end{array}$ & $\begin{array}{c}\text { SE } \\
077113\end{array}$ & $\begin{array}{c}\text { SSE } \\
077113\end{array}$ & $\begin{array}{c}\mathrm{NE} \\
077119\end{array}$ & $\begin{array}{c}\text { ENE } \\
077119\end{array}$ & $\begin{array}{c}\mathrm{E} \\
077120\end{array}$ & $\begin{array}{c}\text { ESE } \\
077121\end{array}$ & $\begin{array}{c}\mathrm{SE} \\
077122\end{array}$ & $\begin{array}{c}\text { SSE } \\
076123\end{array}$ \\
\hline \multirow{4}{*}{10} & $\mathrm{H}_{\mathrm{o}}(\mathrm{m})$ & 5.86 & 5.40 & 4.64 & 3.94 & 4.52 & 4.99 & 5.92 & 5.78 & 4.59 & 5.53 & 5.91 & 6.15 \\
\hline & $\mathrm{H}_{\mathrm{p}}(\mathrm{m})$ & 4.85 & 4.77 & 4.17 & 3.46 & 3.81 & 3.84 & 4.73 & 5.19 & 3.65 & 3.92 & 3.85 & 3.73 \\
\hline & $\mathrm{T}_{\mathrm{o}}(\mathrm{s})$ & 11.12 & 10.68 & 9.81 & 8.47 & 9.02 & 9.58 & 10.99 & 10.81 & 8.82 & 9.41 & 9.71 & 10.06 \\
\hline & $\mathrm{T}_{\mathrm{p}}(\mathrm{s})$ & 10.64 & 10.64 & 9.68 & 8.81 & 8.81 & 9.68 & 11.39 & 10.34 & 8.52 & 9.39 & 9.39 & 10.34 \\
\hline \multirow{4}{*}{20} & $\mathrm{H}_{\mathrm{o}}(\mathrm{m})$ & 6.13 & 5.94 & 6.05 & 4.83 & 5.92 & 6.34 & 6.17 & 6.05 & 6.03 & 7.34 & 7.76 & 8.04 \\
\hline & $\mathrm{H}_{\mathrm{p}}(\mathrm{m})$ & 5.06 & 5.20 & 5.35 & 4.21 & 4.94 & 4.79 & 4.97 & 5.46 & 4.79 & 5.11 & 4.89 & 4.49 \\
\hline & $\mathrm{T}_{\mathrm{o}}(\mathrm{s})$ & 11.37 & 10.90 & 10.72 & 9.38 & 10.33 & 10.80 & 11.22 & 11.06 & 10.11 & 10.84 & 11.13 & 11.50 \\
\hline & $\mathrm{T}_{\mathrm{p}}(\mathrm{s})$ & 11.70 & 10.64 & 10.64 & 9.68 & 10.64 & 10.64 & 11.39 & 11.39 & 10.34 & 10.34 & 11.39 & 11.39 \\
\hline \multirow{4}{*}{30} & $\mathrm{H}_{\mathrm{o}}(\mathrm{m})$ & 6.27 & 6.77 & 6.97 & 5.35 & 6.80 & 7.15 & 6.30 & 6.20 & 6.93 & 8.47 & 8.92 & 9.22 \\
\hline & $\mathrm{H}_{\mathrm{p}}(\mathrm{m})$ & 5.17 & 5.92 & 6.17 & 4.64 & 5.62 & 5.38 & 5.10 & 5.60 & 5.49 & 5.84 & 5.48 & 4.92 \\
\hline & $\mathrm{T}_{\mathrm{o}}(\mathrm{s})$ & 11.50 & 11.63 & 11.50 & 9.87 & 11.06 & 11.46 & 11.34 & 11.19 & 10.84 & 11.64 & 11.93 & 12.31 \\
\hline & $\mathrm{T}_{\mathrm{p}}(\mathrm{s})$ & 11.70 & 11.70 & 11.70 & 9.68 & 10.64 & 11.70 & 11.39 & 11.39 & 10.34 & 11.39 & 11.39 & 12.54 \\
\hline \multirow{4}{*}{50} & $\mathrm{H}_{\mathrm{o}}(\mathrm{m})$ & 6.43 & 7.83 & 8.18 & 6.01 & 7.94 & 8.18 & 6.49 & 6.37 & 8.11 & 9.96 & 10.44 & 10.76 \\
\hline & $\mathrm{H}_{\mathrm{p}}(\mathrm{m})$ & 5.29 & 6.84 & 7.25 & 5.21 & 6.54 & 6.13 & 5.29 & 5.76 & 6.38 & 6.81 & 6.26 & 5.45 \\
\hline & $\mathrm{T}_{\mathrm{o}}(\mathrm{s})$ & 11.66 & 12.51 & 12.47 & 10.46 & 11.96 & 12.27 & 11.54 & 11.35 & 11.73 & 12.62 & 12.91 & 13.30 \\
\hline & $\mathrm{T}_{\mathrm{p}}(\mathrm{s})$ & 11.70 & 12.86 & 12.86 & 10.64 & 11.70 & 11.70 & 11.39 & 11.39 & 11.39 & 12.54 & 12.54 & 13.82 \\
\hline \multirow{4}{*}{100} & $\mathrm{H}_{\mathrm{o}}(\mathrm{m})$ & 6.64 & 9.30 & 9.92 & 6.90 & 9.58 & 9.61 & 7.78 & 7.07 & 9.80 & 12.08 & 12.60 & 12.95 \\
\hline & $\mathrm{H}_{\mathrm{p}}(\mathrm{m})$ & 5.44 & 8.15 & 8.88 & 5.95 & 7.87 & 7.18 & 6.47 & 6.25 & 7.56 & 7.91 & 7.25 & 6.22 \\
\hline & $\mathrm{T}_{\mathrm{o}}(\mathrm{s})$ & 11.84 & 13.64 & 13.73 & 11.20 & 13.13 & 13.29 & 12.63 & 11.41 & 12.89 & 13.90 & 14.18 & 14.60 \\
\hline & $\mathrm{T}_{\mathrm{p}}(\mathrm{s})$ & 11.70 & 14.13 & 14.13 & 10.64 & 12.86 & 12.86 & 12.54 & 11.39 & 12.54 & 13.82 & 13.82 & 15.22 \\
\hline
\end{tabular}

※ Dark background means the greatest wave height for each return period 
한 수치실험을 수행하고 4개 정점에 대한 천해설계파(Table 4의 $\mathrm{H}_{\mathrm{p}}$ 와 $\mathrm{T}_{\mathrm{p}}$ 로 표시)를 산정하였다. 실험 영역은 Fig. 3과 같으며, 입사파랑 선정은 4개 관측점으로 전달될 수 있는 파 랑 추산위치와 파향을 고려하여 선정하였으며, 실험대상 파 랑은 총 5 개 빈도별(10년, 20년, 30년, 50년, 100년)로 총 6 개 파향(속초와 묵호는 NNE, NE, ENE, E, ESE, SE, 후 포와 진하는 $\mathrm{NE}, \mathrm{ENE}, \mathrm{E}, \mathrm{ESE}, \mathrm{SE}, \mathrm{SSE})$ 의 파랑 조건들 을 선정하고 4 개 관측 정점별로 구분하여 각각의 조건에서 수치실험을 수행하였다. 실험결과로 얻은 천해설계파 중에서 빈도별로 가장 큰 파고를 Table 4에서 짙은 바탕으로 표현 하였다.

수치실험 결과를 살펴보면, 속초와 묵호의 경우는 10 년과

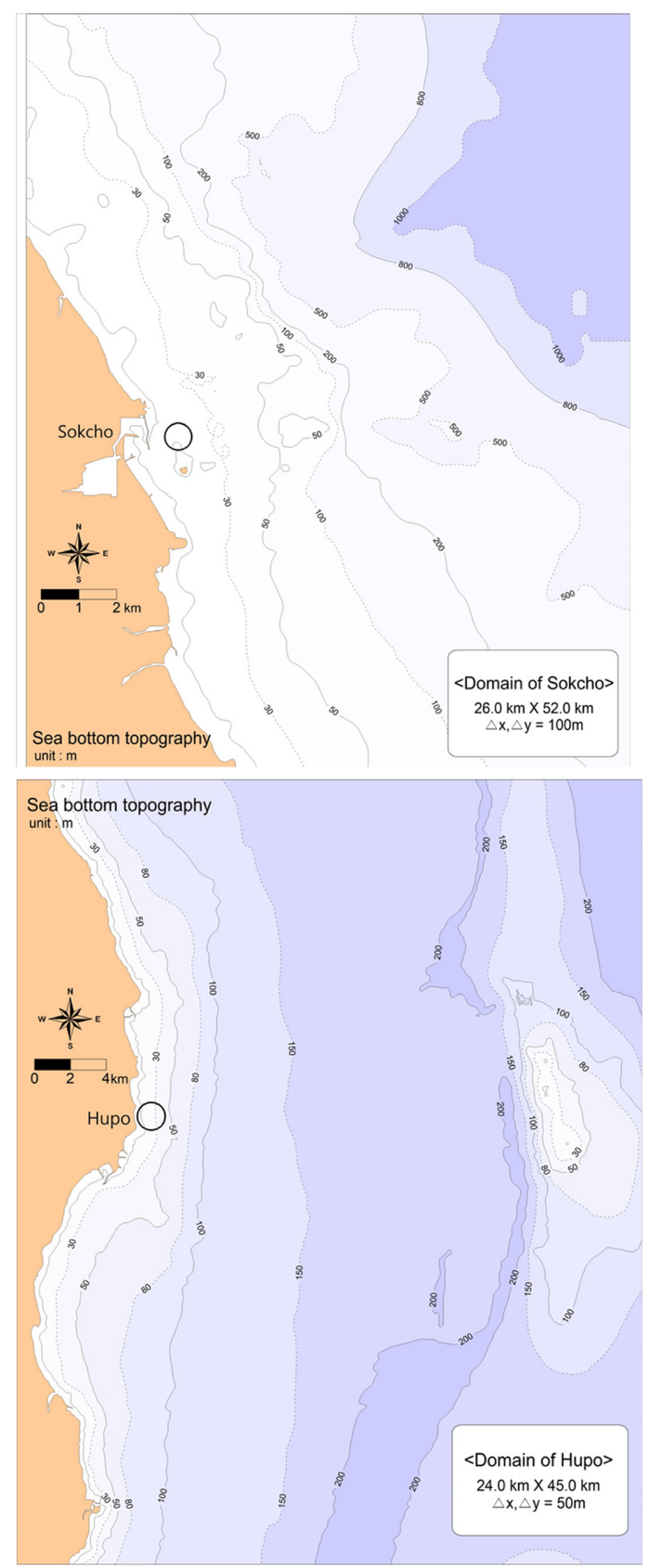

Fig. 3. Computational domains and location of the wave stations.

Fig. 3. Computational domains and location of the wave stations.
20 년 빈도에서 NE 파향에서 가장 큰 파고가 나타났으며, 30 년빈도 이상에서 속초는 $\mathrm{ESE}$ 파향이, 묵호는 $\mathrm{ENE}$ 파향과 $\mathrm{E}$ 파향에서 가장 큰 파고가 나타났다. 후포의 경우는 10 년빈도 에서 $\mathrm{NE}$ 파향에서 가장 큰 파고가 나타났고 나머지 모든 빈 도에서 $\mathrm{E}$ 파향이 가장 크게 나타났다. 진하의 경우는 10 년과 20 년빈도에서 $\mathrm{ENE}$ 파향이, 30 년빈도 이상에서 $\mathrm{ESE}$ 파향의 파고가 가장 크게 나타났다. 빈도별 최대파고는 20 년빈도의 경우 최소 $4.99 \mathrm{~m}$ (속초, $\mathrm{NE}$ )부터 최대 $5.46 \mathrm{~m}$ (진하, $\mathrm{ENE}$ )의 범위이고, 50 년빈도의 경우 최소 $6.05 \mathrm{~m}$ (속초, $\mathrm{ESE}$ )부터 최 대 $7.25 \mathrm{~m}$ (후포, $\mathrm{E}$ )의 범위로 나타나 정점별로 약 $1.5 \mathrm{~m}$ 와 $1.2 \mathrm{~m}$ 의 차이를 나타내었으며, 북측 해역(속초, 묵호)보다 남 측 해역(후포, 진하)의 파고가 더 크게 추산되었다.
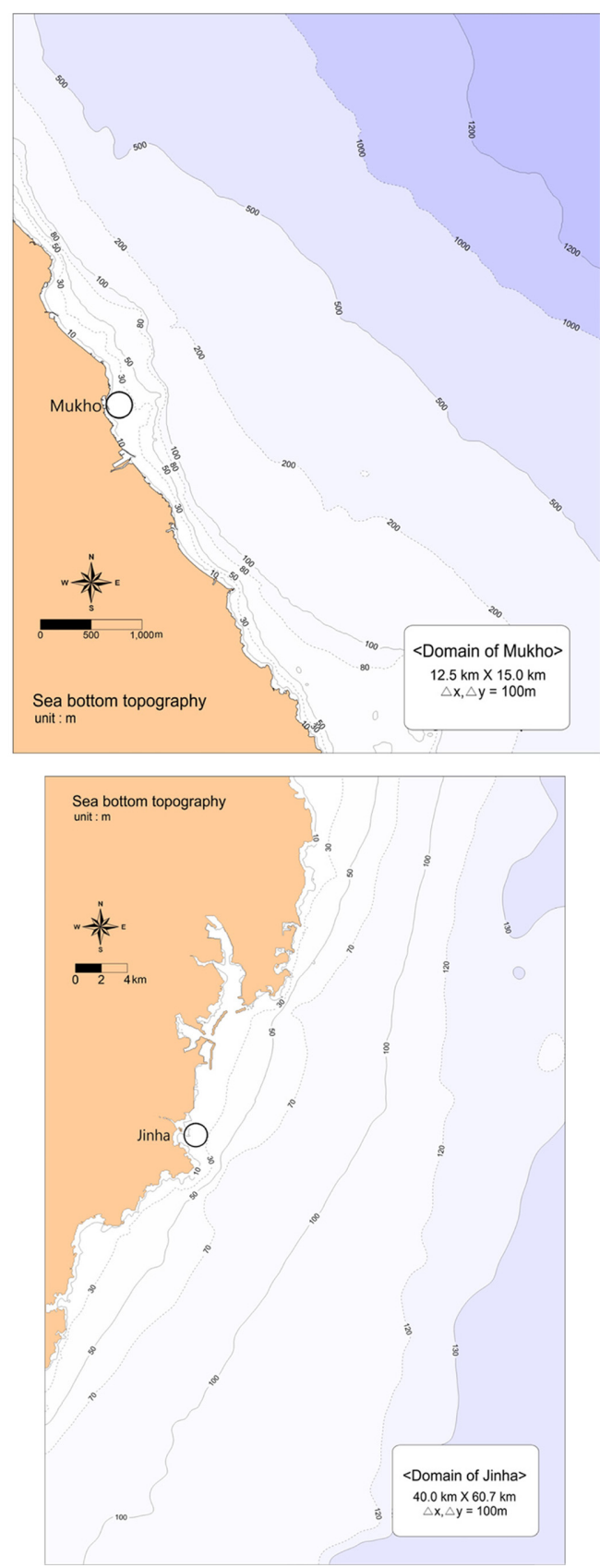

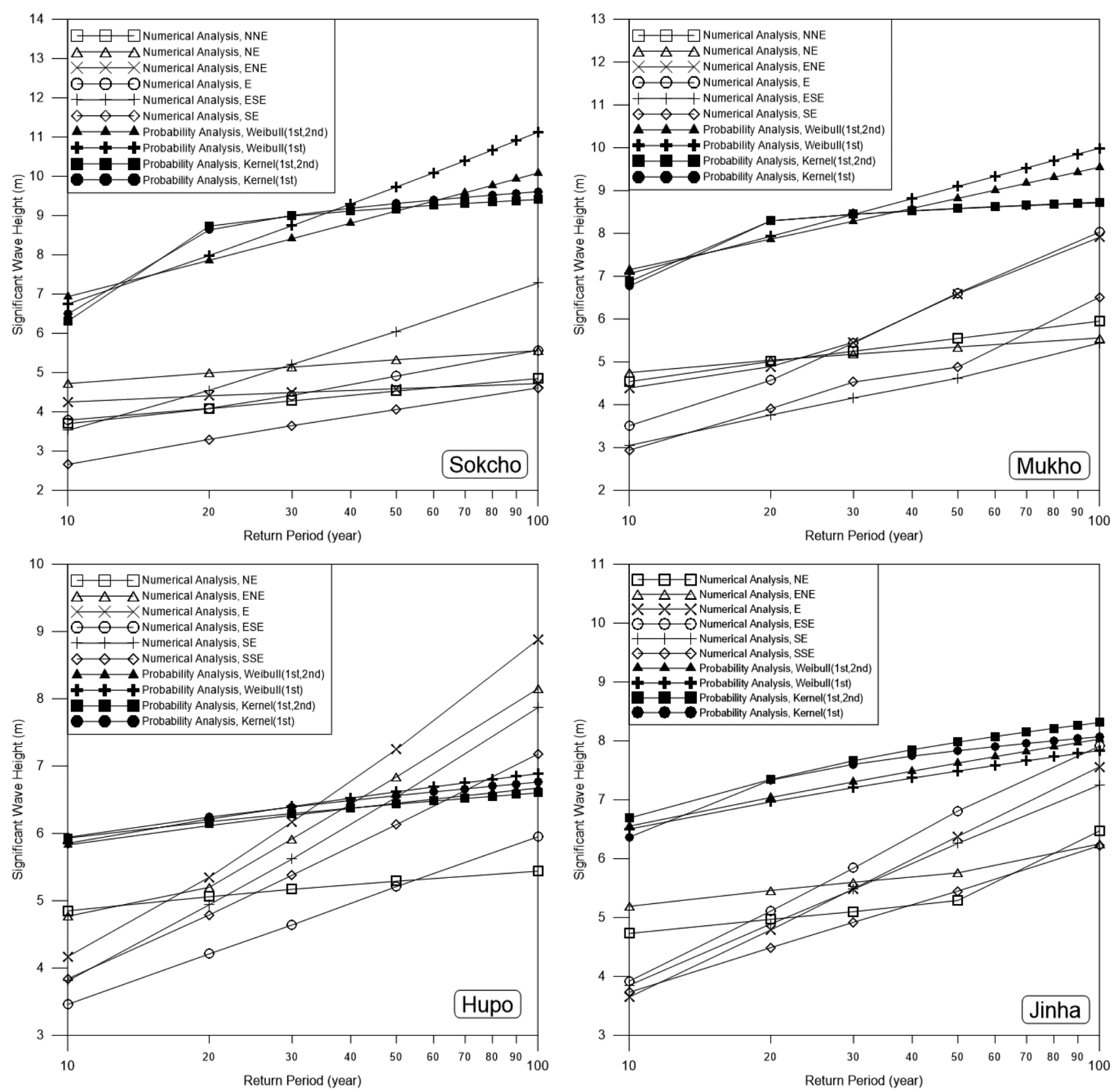

Fig. 4. Significant wave height for different return periods estimated from numerical simulation and statistical analysis.

\section{5. 관측파랑 분석결과와 역추산 실험결과 비교}

관측파랑을 이용한 빈도별 천해설계파 추산결과(Probability Analysis)와 역추산된 심해설계파를 이용한 수치실험 결과 (Numerical Analysis)를 비교하였다. 수치실험 결과는 파향별 모든 결과를 함께 도시하였고, 4개 정점별로 Fig. 4에 나타 내었다. Fig. 4에 따르면, 속초, 묵호, 진하는 관측파랑을 이 용한 천해파 추산결과가 더 크게 나타났으며, 빈도별로 차이 는 있으나 속초는 1.8 3.2 m, 묵호는 0.7 2.8 m, 진하는 최대 $1.5 \mathrm{~m}$ 까지 차이를 나타내었다. 후포는 30 년빈도 이하에서 관 측파랑을 이용한 천해파 추산결과가 $0.1 \sim 1.0 \mathrm{~m}$ 더 크게 나 타났으나, 30년 이상의 빈도에서 역추산된 심해파를 이용한
수치실험 결과가 $0.8 \mathrm{~m}(50$ 년빈도 $)$ 와 $2.3 \mathrm{~m}$ (100년빈도) 더 크 게 나타났다.

Fig. 5는 역추산된 심해파로부터 수치실험을 수행하여 추 산한 천해설계파의 전 파향 중에서 최대파고를 빈도별로 도 시하고 직선 회귀분석을 수행하였으며, 4 개 정점에서 관측된 연최대파고 $\left(\mathrm{Hs}_{1}\right)$ 를 5 개씩 큰 파고 순서대로 추출(Table 2 참 조)하여 도시된 회귀분석 그래프에 함께 나타내었다. 결과에 따르면, 속초의 최대 관측파고는 $8.95 \mathrm{~m}$ 로 재귀년도 156 년에 이르며, 묵호도 $8.37 \mathrm{~m}$ 로 재귀년도 106 년에 해당된다. 후포 의 최대 관측파고는 $5.94 \mathrm{~m}$, 재귀년도는 29 년, 진하의 최대 관측파고는 $7.52 \mathrm{~m}$, 재귀년도는 82 년으로 나타났다.

이와 같이 후포를 제외한 다른 정점에서 재귀년도가 상당 

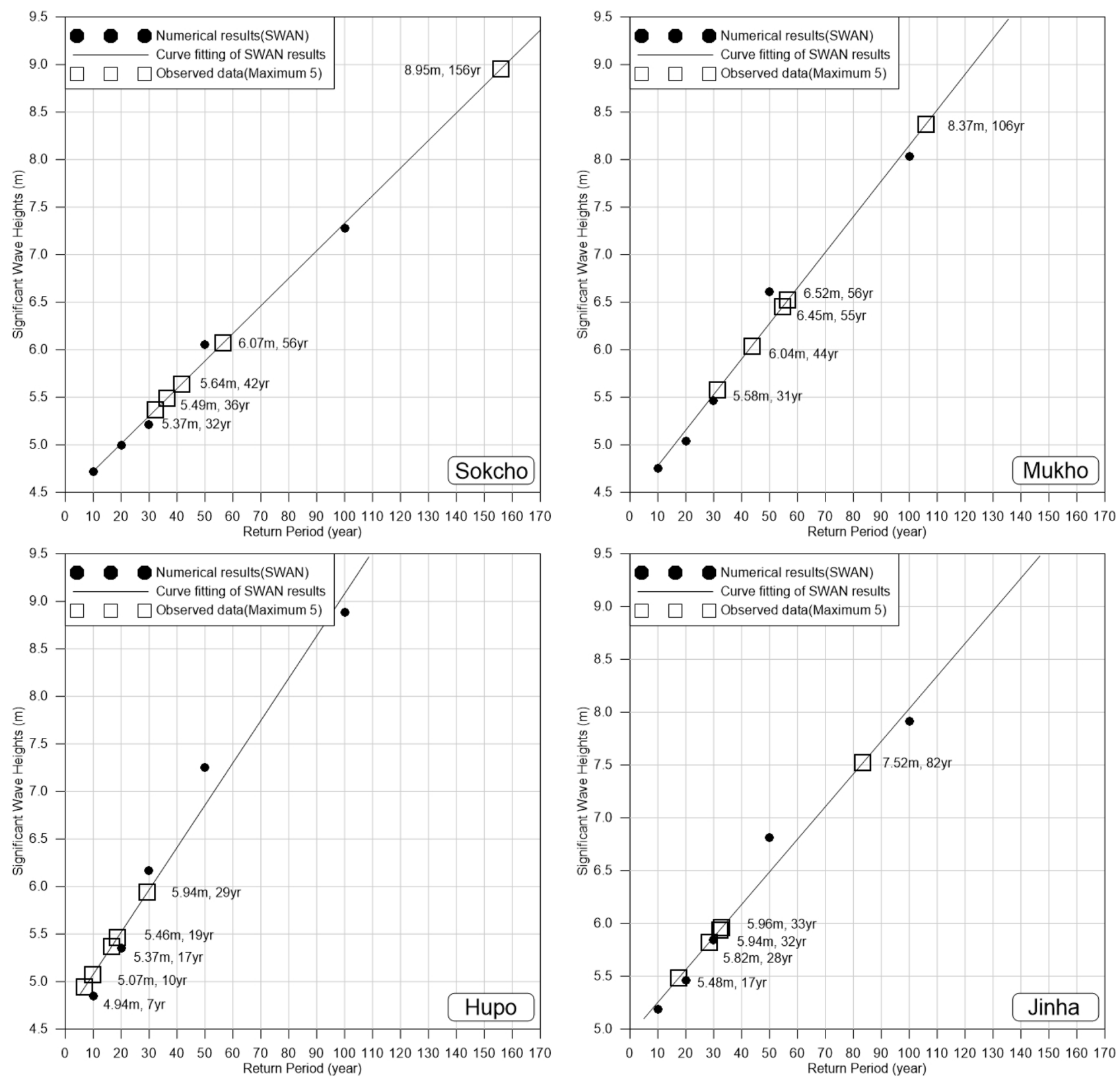

Fig. 5. Curve fitted relationship between the significant wave height and the return period together with the top 5 wave heights data from SWAN simulation and observation.

히 크게 추정된 이유는 2 가지로써, 이는 최근 동해안에 내습 이 잦은 고파랑의 영향일 수도 있고 또는 2005년 당시 심해 설계 추산이 다소 과소추정된 것으로 생각해 볼 수도 있다. Table 4에서 20년 또는 30년빈도 이상의 파랑에서 E 또는 $\mathrm{ESE}$ 파향이 최대파랑으로 선정된 것은 태풍의 영향이 주로 반 영된 것으로 보이지만, 동해안 관측파랑의 주파향 $(\mathrm{NE}$ 또는 $\mathrm{ENE}$ )을 고려할 때 $\mathrm{E}$ 또는 $\mathrm{ESE}$ 파랑은 다소 과대 추정되고, 상 대적으로 $\mathrm{NNE}$ 또는 $\mathrm{NE}$ 파랑은 과소 추정된 것으로 판단된다.

동해안의 파랑 특성을 지형적으로 구분하면 3개 구역(1구 역 : 대진 죽변 해역, 2구역 : 죽변 장기갑 해역, 3구역 : 장 기갑 울산 해역)으로 구분할 수 있으며, 1 구역은 $\mathrm{NE}$ 방향으 로, 2 구역은 $\mathrm{E}$ 방향으로, 3 구역은 $\mathrm{ESE}$ 방향과 대략적으로 수
직을 이루는 지형적 특성을 가지고 있다. 속초와 강릉은 1 구역 을, 후포는 2 구역을, 경주는 3 구역을 대표한다고 가정할 때, 4 개 지점에서 최근 약 3 4년간 파향이 포함된 파랑관측 결과 로부터 유도된 파랑장미도(Fig. 6. 참조)를 살펴보면, 구역과 상관없이 동해안의 실제 내습파랑은 대부분 $\mathrm{NE}$ 와 $\mathrm{ENE}$ 파 향에서 나타나는 것을 알 수 있다. 이러한 점을 고려할 때 Table 4에서 20년 또는 30년 빈도 이상의 파랑에서 E 또는 $\mathrm{ESE}$ 파향이 최대파랑으로 선정된 것은 태풍의 영향이 주로 반영된 것으로 판단되며, 반면에 $\mathrm{NE}$ 계열 파랑이 최대파랑 으로 선정되지 않은 것은 심해설계파 추산 시 과소 추정되었 기 때문인 것으로 판단된다. 이는 태풍을 모의할 때 짧은 시 간동안 출현하는 최대파고가 적절하게 재현되지 못했을 수 있 


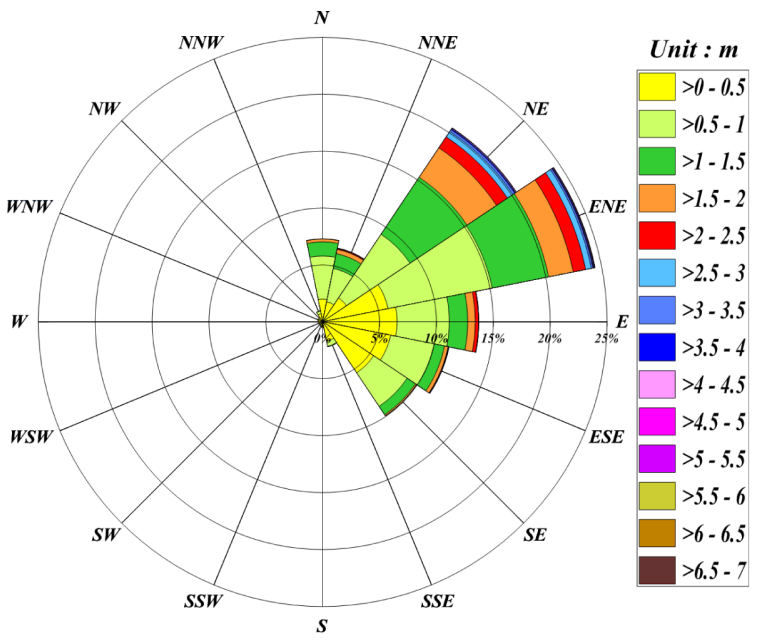

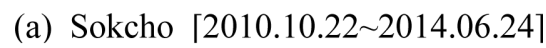

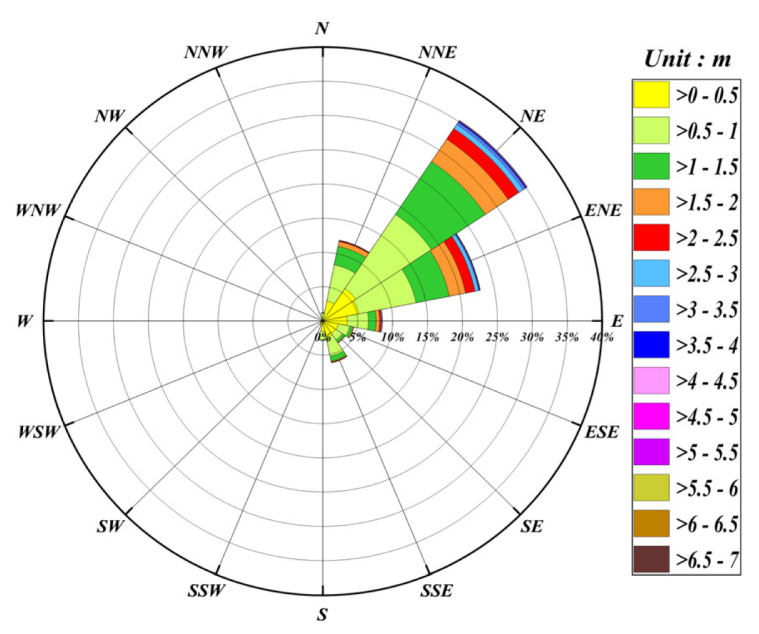

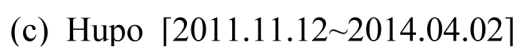

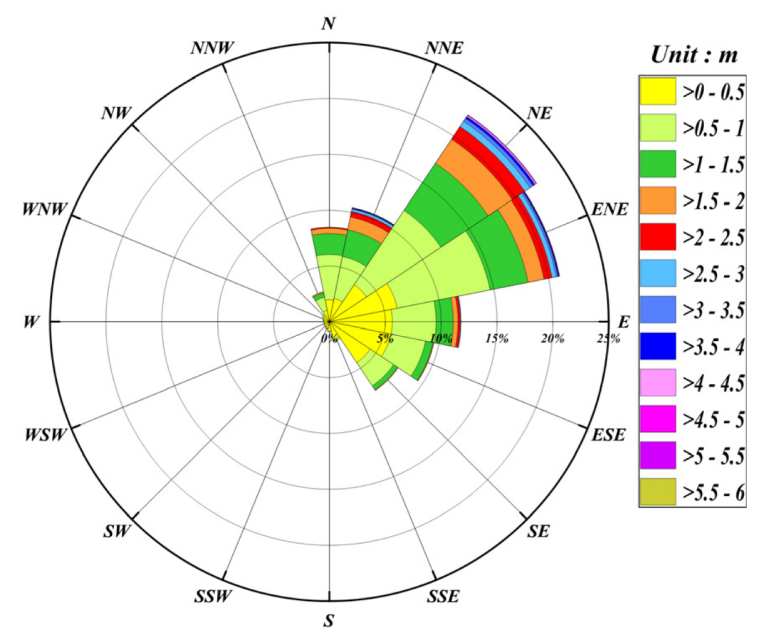

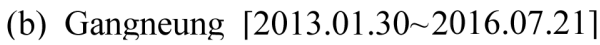

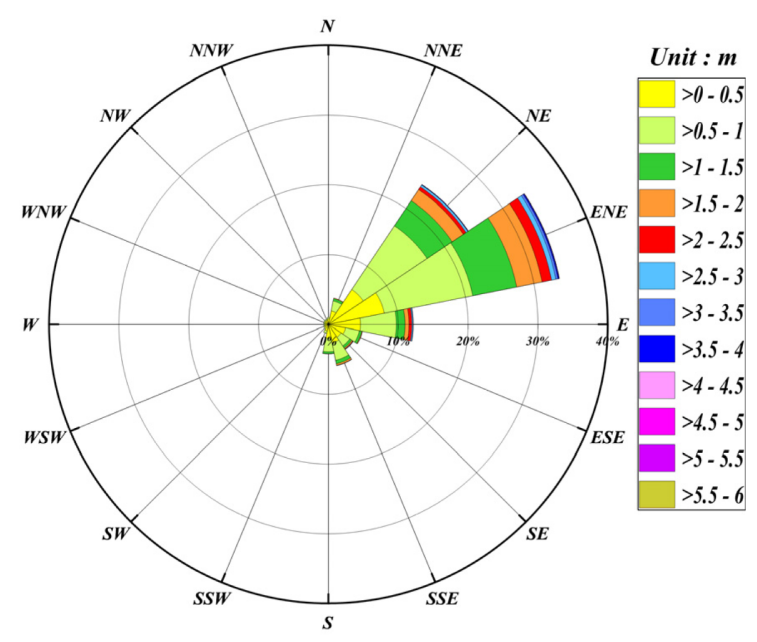

(d) Gyeongju 「2014.07.21 2016.08.11]

Fig. 6. Observed wave roses at Sokcho, Gangneung, Hupo and Gyeongju.

고 시시각각 변화하는 파랑의 파향이 그대로 분석에 적용되 었기 때문일 수도 있을 것으로 추정된다.

\section{6. 토의 및 결론}

본 연구에서는 우리나라 동해안에 위치한 4개 정점(속초, 묵호, 후포, 진하)에서 약 13 년간 관측된 파랑자료로부터 연 최대 유의파 또는 연2위 유의파를 이용하여 2 개의 극치확률 분포함수(Weibull 분포 및 Kernel 분포함수)에 적합시켜 천 해설계파를 추산하였으며, 한국해양연구원(2005)의 역추산된 파향별 심해설계파 자료를 입력조건으로 SWAN 모형을 사 용한 수치실험 결과와 비교·분석하였다.

관측파랑 극치분석 결과는 역추산된 심해파의 수치실험 결 과보다 후포의 30 년빈도 이상을 제외하고 대부분의 경우에서 큰 파고를 나타내었으며, 특히 5년 20년빈도에서는 약 $0.8 \sim 3.0 \mathrm{~m}$
까지 큰 파고 편차를 나타내며 4개 정점 모두에서 파고가 크 게 추산되었다.

역추산된 심해파의 빈도별 수치실험 결과 그래프에서 실제 관측파고를 대입시켜본 결과, 관측기간 중 출현했던 최대파 고들이 후포를 제외하고 상당히 재현기간이 긴 파고에 해당 하는 것으로 추정되었다(속초 $8.95 \mathrm{~m}, 156$ 년, 묵호 $8.37 \mathrm{~m}$, 106년, 후포 $5.94 \mathrm{~m}, 29$ 년, 진하 $7.52 \mathrm{~m}, 82$ 년; Fig. 5. 참조).

이상의 결과로 유추해보면, 2005년에 제시된 동해안의 심해 설계파고는 전체적으로 다소 과소 추정된 것으로 판단된다. 특 히 관측파랑의 주파향을 분석해보면 동해안은 대부분 NE와 $\mathrm{ENE}$ 파향이지만, 2005년 심해파 결과는 재현 빈도가 커질수 록 $\mathrm{E}$ 와 $\mathrm{ESE}$ 파향에서 최대파고가 선정되어 태풍과 비태풍 에 의한 효과가 다소 부적절하게 반영된 것으로 유추된다. 또 한 관측결과의 극치분석 결과 중 5 20년빈도의 파고가 역추 산된 심해파의 수치실험 결과보다 $0.8 \sim 3.0 \mathrm{~m}$ 크게 나타난 것 
을 고려할 때, 2005년 심해파 추산결과가 과소추정된 것으로 이해된다.

\section{감사의 글}

본 논문은 한국해양과학기술원의 주요사업 “연안침식저감 원천기술 개발(PE99423)"과 국토교통부가 주관하고 국토교 통과학기술진흥원이 시행하는 2012년도 지역기술혁신사업(12 지역기술혁신 B01) 연구사업의 지원을 받아 수행되었습니다.

\section{References}

Goda, Y.(2010). Random seas and design of maritime structures. 3rd Edition, Advanced Series on Ocean Engineering. Vol. 33, World Scientific.

Jeong, W.M., Jun, K.C., Kim, G.W., Oh, S.H. and Ryu, K.H. (2012). Shallow-water design waves at Gangreung beach through the analysis of long-term measured wave data and numerical simulation. J. of Korean Society of Coastal and Ocean Engineers, 24(5), 343-351 (in Korean).

Jeong, W.M., Kim S.I., Baek, W.D. and Oh, S.H. (2014). Measurements of storm waves generated by typhoons passed through eastside of Korea Strait from 2004 to 2006. J. of Korean Society of Coastal and Ocean Engineers, 26(2), 65-71 (in Korean).

Jeong, W.M., Ryu, K.H. and Cho, H.Y. (2015). Long-term wave monitoring and analysis off the coast of Sokcho. J. of Korean Society of Coastal and Ocean Engineers, 27(4), 274-279 (in Korean).

Jeong, W.M., Cho, H. and Baek, W. (2015). Analysis of the longterm wave characteristics off the coast of Daejin, Journal of the Korean Society of Coastal and Ocean Engineers, 27(2), 142-147 (in Korean).
Jeong, W.M., Ryu, K.H, Oh, S.H. and Baek, W.D. (2016). Trends of the storm wave appearance on the east coast analyzed by using long-term wave observation data. J. of Korean Society of Coastal and Ocean Engineers, 28(2), 109-115 (in Korean).

Lee, C., Ahn, S.J., Lee, B.W., Kim, S.W. and Kwon, S.J. (2014). Prediction of swell-like high waves using observed data on the east coast of Korea, J. of Korean Society of Coastal and Ocean Engineers, 26(6), 149-159 (in Korean).

Lee, D.-Y. and Jun, K.-C. (2006). Estimation of design wave height for the waters around the Korean Peninsula, Ocean Science Journal, 41(4), 245-254

Lim, D., Suh, K. and Mori, N. (2013). Regional projection of future extreme wave heights around Korean Peninsula, Ocean Science Journal, 48(4), 439-453

Masataka, Y. and Yoshio, H. (2003). Estimation of wave climate and its long-term variability, May 2003. Proceedings of The Thirteenth(2003) International Offshore and Polar Engineering Conference.

Oh, S.H., Jeong, W.M., Lee, D.Y. and Kim, S.I. (2010). Analysis of the reason for occurrence of large-height swell-like waves in the east coast of Korea. J. of Korean Society of Coastal and Ocean Engineers, 22(2), 101-111 (in Korean).

Oh, S.H. and Jeong, W.M. (2013). Characteristics of high waves observed at multiple stations along the east coast of Korea. Natural Hazard and Earth System Sciences, 13, 3503-3514.

Received 8 October, 2016

Revised 24 October, 2016

Accepted 24 October, 2016 